\title{
An International Analysis of the Role of Religion and Spirituality in Social Work Practice
}

\author{
Leola Dyrud Furman, Mari-Anne Zahl, Perry W. Benson, \\ \& Edward R. Canda
}

\begin{abstract}
As service populations have changed, social workers in Norway and the United States have attempted to respond to the needs of diverse cultures, which often include issues of religion and spirituality. Members of the Norwegian Union of Social Educators and Social Workers (FO) and the U.S. National Association of Social Workers (NASW) were sampled to explore attitudes and perceptions of social workers regarding the placement of religion and spirituality in practice. In general, U.S. social workers were more accepting of religion and spirituality than their Norwegian colleagues. Factors such as secularism, functional differences of church and state relations, and different historical trajectories in the social work profession's development in both countries may contribute to differences between the U.S. and Norway.
\end{abstract}

N orth American and European social workers increasingly confront international practice issues and diverse service populations amid mobile and heterogenous societies. The increase in the number of refugees due to ethnic and religious conflicts is one of the challenges that practitioners face in 21 st century, which has resulted in a new set of demands and problems for the social services (Hokenstad \& Midgley, 2004). In modern secular societies, immigrant groups now retain their religious affiliations and cultural identities rather than attempting to achieve assimilation. As Bruce (1995) observed in the United Kingdom, faith-based immigrant groups "are markedly more religious than their host (British) society" (p. 87) and are deeply affected by being "moved abruptly from a society in which their religion was dominant and all-pervasive to a society where they form a deviant minority" (p. 93). The growth of service populations with minority religions, and the quest for religious and spiritual fulfillment by people in general (Bruce, 1995; 1996), have had an impact on how practitioners assess the importance of integrating religion and spirituality into their social work practice (Zahl \& Furman, 2005).

As global phenomena challenge the profession to define its worldwide role, Midgley's (1995) observation that knowledge can be increased by investigating social phenomena in other societies, by testing propositions in different cultural contexts, and by cross-national application of social science findings, is especially relevant to contemporary social work. Furthermore, "despite the growth of social work as an international profession, most social workers are

Families in Society: The Journal of Contemporary Social Services I www.familiesinsociety.org | DOI: 10.1606/1044-3894.3622 
poorly informed about the activities of their colleagues in other countries" (p. 1494). Hokenstad and Midgley (2004) also noted that "it is today generally accepted that mutuality and the reciprocal sharing of knowledge and practice approaches should characterize international exchanges in social work. This implies that social workers in all parts of the world can learn from each other" (p. ix).

As the first, and only, national studies of their kind, survey research was conducted in the United States in 1997 and replicated in Norway in 2002 to examine social workers' views on spirituality, both religious and nonreligious, in relation to social work practice and education. Differences between social workers in the two countries bring to the forefront the complexity and challenges of developing globally sensitive and respectful practices and helping activities that also acknowledge each country's religious and spiritual histories and concerns. The U.S. survey was prompted by a series of regional studies that examined the attitudes of social work practitioners, educators, and students toward spirituality and religion in direct practice (for example, Dudley \& Helfgott, 1990; Sheridan, Bullis, Adcock, Berlin, \& Miller, 1992; Furman \& Chandy, 1994; Sheridan, Wilmer \& Atcheson, 1994; Derezotes \& Evans, 1995; Russel, 1998; Sheridan \& Amato-von-Hemert, 1999; Canda \& Furman, 1999; and Furman \& Fry, 2000).

Although U.S. social workers have explored and debated religion and spirituality in social work practice and policymaking in greater depth, it was not clear how the subject would be received among social workers in the Nordic model of modern welfare states. North American and European countries often study the Nordic model's approach to social welfare policy and practices. According to Salonen (2001), the Nordic countries (i.e., Sweden, Norway, Finland, and Denmark) often serve as idealized and prototypical examples of the institutional welfare model, and "there is strong evidence that these Nordic countries form a distinct group in international comparisons" (p. 144). In 1999, the Norwegian General Plan and Regulations, on which all 3-year social work training programs are based, included a spiritual component (Rammeplan, 1999). Additionally, Norway has experienced an increase in service populations with diverse religious and spiritual worldviews. What impact might this have on how Norwegian social workers assess the importance of religion and spirituality in their practices? As an opportunity to reflect on our own practices, what can Norwegian and U.S. social workers learn from each other regarding the integration of religion and spirituality in social work practice?

\section{Review of the Literature}

\section{Cultural Factors in the United States}

According to the U.S. Census Bureau (2000b), there are roughly 287 million people in the United States, of which
$10.4 \%$ are foreign born. The United States has approximately 35 million Hispanics, 35 million African Americans, 10 million Asian Americans, and 2 million indigenous peoples (i.e., American Indians, Alaskan natives, and Native Hawaiians). According to Hutchison (2003), the United States is the "first country in the world's history to be a microcosm of the world in race, ethnicity, and religion" (p. 27).

A number of polls have consistently reported that between $92 \%$ and $97 \%$ of Americans say that they believe in God or a higher power, and $87 \%$ report that religion is either "very" or "fairly important" in life (Gallup \& Lindsay, 1999). These statistics indicate a strong thread of religious and nonreligious spirituality in the United States, which now has over 900 religions (Melton, 1993). By 1996, nonreligious affiliations such as atheism had increased $13.2 \%$, and regular attendance at religious services had decreased from $49 \%$ in 1991 to $36 \%$. Christianity, Judaism, and Islam, however, continue to have the highest number of affiliates in the United States (Sheridan, 2003).

\section{Cultural Factors in Norway}

Norway has an increasingly more heterogenous population of nearly 4.6 million, of which $7.6 \%$ are foreign born or have two foreign-born parents, and a state church based on the Evangelical Lutheran Faith. Approximately $86 \%$ of the population belongs to the state church, but only $10 \%$ report church attendance of once a month or more (Davie, 1999). Membership is gained through baptism. In 2003, approximately $78 \%$ of the infants born were baptized. Almost $9 \%$ of Norwegians are members in religious or philosophical communities outside the Church of Norway (Statistics Norway, 2004).

Recently, there has been a marked increase in membership in other religious groups, particularly in Islamic societies and the Roman Catholic Church. According to the Norwegian Constitution, religious freedom is granted to the inhabitants of the country. Religion is included in elementary and high school curricula. Because there is no separation of church and state, the state handles mundane problems as well as spiritual matters such as baptism, marriage, and death (Sejersted, 2003).

During the 1970s, membership cancelations in the State Church increased. According to Roof and Aagedal (1996), the student revolution in Norwegian universities was "dominated by left-wing ideology. Views on religion were strongly influenced by Marxism, in which metaphysical and religious questions were considered to be false questions that diverted attention from important political problems" (p. 152). Botvar (1996) observed that "Norwegians are not on the whole devout, yet they are certainly not an irreligious people-seven out of ten believing in God or in a "higher power"' (p. 122).

The Humanistic-Ethical Society (HEF), which was formed in 1956 as nonreligious humanistic organization, 
has worked to gain the right to perform "churchlike" services such as namegiving, confirmation, weddings, and funerals, which are all central parts of church functions. The HEF offers alternatives for important events in peoples lives-literally from infancy to death. Due to its emphasis on secular humanism, the HEF is critical of the State Church (Roof \& Aagedal, 1996, p. 153).

\section{An Overview of Religion and Spirituality in U.S. Social Work}

The interest in religion and spirituality within the social work profession has developed in four broadly defined phases (Canda \& Furman, 1999; Canda, 2002). The sectarian roots phase, which began with the colonial period and lasted through the early 20 th century, consisted of human services and institutions influenced by Judeo-Christian worldviews on charity, communal responsibility, and justice. The period from the $1920 \mathrm{~s}$ through the 1970s delimits the second phase, which was characterized by the drive toward professionalization and secularization (Russel, 1998; Canda \& Furman, 1999). The third phase, from the 1980 s to mid1990s, was marked by a resurgence of interest in religion and spirituality in social work, especially under the rubric of cultural diversity. This phase was characterized by a marked increase in the number of publications and presentations on the topic, and the development of a national Society for Spirituality and Social Work. The beginning of the fourth phase can be set in 1995, when the Council on Social Work Education reintroduced references to religion and spirituality into its Curriculum Policy Statement (Canda \& Furman, 1999; Canda, 2002; CSWE, 2001; and CSWE, 2003). Publications, presentations, and networking on spirituality in social work have expanded even more rapidly since then, most notably extending to interprofessional and international scopes. This trend toward reexamination and reintegration of spirituality within the profession reflects similar developments within the larger U.S. culture (Gallup \& Lindsay, 1999; Sheridan, 2003, pp. 248-249).

\section{An Overview of Religion and Spirituality in Norwegian Social Work}

The forerunners of social work education in Norway were women deeply concerned with the living conditions of their fellow citizens, who sought to contribute to the betterment of Norwegian society. The Norwegian Women's National Council (Norske Kvinners Nasjonalråd Beretning [1904-1907] - NKN) was established in 1904. Their main purposes were to guard women's professional, economic, and social rights, and to stimulate women to contribute to society (Ulsteen, 1990). By 1920, NKN started a one-year program called Sociale Kurser (Social Courses). Alice Salomon's program in Berlin, which combined theory and practice, influenced Norway's program. Both the NKN and Salomon set up the program for women only. The Courses were established in Oslo and accepted applicants from the whole country to establish professional solidarity (Kiær, 1951). Aaslaug Aasland (1937), a prominent lawyer and public official who promoted and directed the Courses, spelled out the ideological base that infused social work at this time: sympathy, charity, justice, and equality. In affiliation with social democratic ideals, she advocated for a society that promoted social justice for all of its inhabitants. In 1950, the first government-operated school for men and women in social work opened in Oslo. The program was heavily influenced by the expansion of the bureaucratic system, social policies, and the legal system.

At present, the most recent General Plan for health and social workers (Rammeplan, 1999) states that the helping professions are to work in accordance with a holistic view of clients to serve them well, which includes the physical, psychological, social, cultural, and spiritual aspects of human existence (p. 19). The social work profession has been slow to respond to these new governmental requirements, as noted by the absence of discussions, conferences, and publications exploring how these requirements should be implemented. To date, only this study has examined the views and attitudes of Norwegian social work practitioners about integrating religion and spirituality into curriculum and practice.

\section{The Influence of Secularization on U.S. and Norwegian Social Work}

The profession of social work in Norway corresponds roughly to the second phase of U.S. social work (1920s to 1970s), when professionalization and secularization dominated the profession. This period coincides with the first social work courses offered to female social workers in 
Norway. Social work education in Norway was delayed by World War II in the decade from 1940 to 1950. From 1950 on, the focus of the newly opened school of social work was directed toward managing a steadily growing bureaucracy designed to assist citizens. During the late 1960s and 1970s, schools of social work in Norway were strongly influenced by the ideology of Marx and his views that religion would vanish with the disappearance of differences based on social class. These overlapping historical trajectories in the United States and Norway are congruent with the movement toward secularized societies in North America and Europe (Furman, Benson, Grimwood \& Canda, 2004).

Berger (1999), a central figure in discussions of modernity and secularization, noted that the secular world predicted by analysts has not materialized as expected. Recent studies in France, Britain, and Scandinavia reveal that Christianity still thrives, although it appears to manifest largely outside of the confines of organized religion. Berger noted that "a shift in the institutional location of religion,...rather than secularization, would be a more accurate description of the European situation" (p. 10).

Given the high levels of religiosity in the United States, Bruce (1996) has speculated that the ethnic diversity of the U.S. population could be one mediating factor. Shared religious beliefs tend to survive the linguistic and cultural changes that confront immigrant groups. Religious organizational involvement tends to be a staple of the American experience, even though the popularity of religion may periodically change (p. 162). It should also be noted that social inequalities and economic uncertainties are underlying realities for Americans. Many Americans are also deprived of adequate health care and child care services (especially for those employed at minimum wage). The citizens of European social democracies, however, may not have to worry about these basic needs to the same extent. Organized religion in the United States often plays a key role in mediating these issues and in providing social and psychological support for its members.

\section{Methodology}

\section{Design and Data Collection}

The Norway and U.S. samples were culled from the membership mailing lists of the Norwegian Union of Social Educators and Social Workers (FO) and the National Association of Social Workers (NASW) in the United States. Based on the U.S. Census Bureau (2000a) Regional Divisions (i.e., Northeast, Midwest, South, and West), a stratified-random sample of 8,000 practicing social workers was selected from the NASW membership list. To avoid sampling some of the same members twice, the survey population was selected by officials at NASW headquarters in Washington, DC, based on members' self-reported primary practice area. Members reporting the following primary practice areas were sampled: Child/Family Welfare, Criminal Justice, Medical/Health Care, Mental Health, Occupational SWK-EAP, School Social Work, and Other. These practice areas identified the professional orientation of the service that the NASW member was providing, regardless of place of employment or role in that service. Two thousand questionnaires were mailed to each region. Six weeks later, a replacement was sent to those who had not returned the survey. A total of 2,069 questionnaires were returned, representing a $26 \%$ response rate (Canda \& Furman, 1999).

Among the 6,011 social work members of the FO, 2,000 employed social workers were randomly sampled and sent a survey instrument, a reply envelope, and an introductory letter authorized by the head of the union and the researcher. Due to confidentiality, follow-up letters to remind potential respondents to participate were not allowed. The FO and the European Union have strict guidelines in place to protect the anonymity of respondents. The study, however, was introduced in the national journal (Embla) published by the Norwegian Social Work Union, and a general reminder was published therein. Some envelopes came back to the sender due to wrong addresses, but 601 survey instruments (which is the equivalent of $10 \%$ of the total FO membership) were completed and returned for a return rate of $30.3 \%$.

\section{Survey Instruments}

Description of the instruments. The original survey instrument was developed in the United States for a 1997 national survey of social workers in specific areas of direct practice who were members of the National Association of Social Workers (NASW). The questionnaire was shortened and adapted for use in the United Kingdom. It consisted of 63 items that included demographic, education, and practice information (Furman et al., 2004). The United Kingdom survey instrument was translated from English into Norwegian. The survey instrument was adapted for culturally appropriate information that pertained to Norway, such as education level and geographic location of practice, before it was administered.

Definition of terms. The Norway and U.S. instruments began with definitions of religion and spirituality for the purpose of the survey. Religion was defined as "an organized structured set of beliefs and practices shared by a community related to spirituality." Spirituality, on the other hand, was defined as the "search for meaning, purpose, and morally fulfilling relations with self, other people, the encompassing universe, and ultimate reality however a person understands it. Spirituality may be expressed through religious forms, but is not limited to them" (Canda 1990a; 1990b; Canda \& Furman, 1999).

Validity and reliability. The questionnaire was subjected to content validity, criterion-referenced concurrent validity, discriminant validity, and principal components 
analysis (Canda \& Furman, 1999; Furman et al., 2004). The principal components analysis (PCA) yielded scales for the religion items (Norway Cronbach's alpha $=.96$; United States Cronbach's alpha $=.97$ ), the spirituality items (Cronbach's alpha $=.96$ for both Norway and the United States), and a combined religion and spirituality scale (Cronbach's alpha $=.97$ for both Norway and the United States) (Canda \& Furman, 1999; Furman et al., 2004). Cronbach's alpha, a statistic that indicates how well individual items work together to produce a viable measure (Nunnally, 1978), was computed for each of the scales to determine internal consistency. The high-coefficient alphas suggested strong internal consistency for the measurement scales.

Limitations. There are special methodological concerns in cross-cultural research, such as (1) the quality of data collection and accuracy of data entry, (2) the selection of appropriate analytic techniques for comparative research, and (3) the influence of bias in interpreting findings (Midgley, 1995, pp.1490-1493). Such concerns in this research were mitigated by researchers from both Norway and the United States. Steps were taken to ensure that data were entered accurately by checking the data entry process twice in the United States. In Norway, the data were precoded and scanned. Also, a multinational team was used to guard against cultural bias in the design of the survey instrument and in the interpretation of the findings.

It was expected that those social workers who had an active interest in the subject of religion and spirituality, either pro or con, would complete and return the questionnaire. These studies are exploratory and suggestive rather than definitive, and indicate a need for future studies with much larger response rates than the $26 \%$ and $30.3 \%$ obtained for the United States and Norway, respectively. There was also a gap of 5 years between data collection points. Patterns in the United States are now likely to show even more support for dealing with spirituality in social work, and for somewhat higher levels of educational exposure, due to increased support in the NASW code of ethics, CSWE curriculum standards, and increased numbers of publications and courses. Because of this, it is possible that there is an even bigger gap between Norway and the United States than suggested in the data.

A translation presents semantic challenges on several levels. A literal translation is the simplest, although the equivalent word might not convey the same meaning. This study was part of an international comparison and had to bring forth comparable results on the given scales. Thus, some of the questions related to social work activity were kept or adapted even though they might not be pertinent to Norwegian culture. The English version of the survey was translated by a native Norwegian speaker, then discussed with students in social work, social work faculty, social workers in practice, and faculty of a religion department.

\section{The Research Findings}

\section{Sample Characteristics}

Limited information regarding the FO's membership was available. In terms of gender, the Norway sample mirrored the FO membership ( $81 \%$ women, $19 \%$ men). Based on Gibelman and Schervish (1997), the U.S. survey closely resembles the NASW membership demographics. The total number of social and human service workers was estimated at 666,000 , although only 153,814 , or approximately $32 \%$, were actual NASW members (Gibelman \& Schervish, 1997, p. 5). The majority of respondents were female $(74.4 \%, n=1,539 ; 78.3 \%$ NASW $)$ compared with $24.7 \%(n=512)$ males $(21.7 \%$ NASW $)$. The education levels of the respondents in the survey were also in close alignment with the NASW findings: BSW/BA $(2.3 \%, n=$ 48; 5.8\% NASW), MS/MA/MSW (90.6\%, $n=1876 ; 90.1 \%$ NASW), and $\mathrm{PhD} /$ postdoctorate $(5.9 \%, n=122 ; 4.1 \%$ NASW). This was also true for level of employment: fulltime $(74.5 \%, n=1541 ; 77.8 \%$ NASW $)$ and part-time $(21.3 \%, n=440 ; 22.2 \%$ NASW). The majority of the respondents were Caucasian/European American (89.3\%, $n=1847 ; 88.5 \%$ NASW). Other ethnic groups represented in the survey were African Americans (3.5\%, $n=73 ; 5.3 \%$ NASW), Hispanic Americans ( $1.6 \%, n=34 ; 2.8 \%$ NASW), Asian Americans/Pacific Islanders $(1.1 \%, n=23 ; 1.7 \%$ NASW), Native Americans ( $0.7 \%, n=15 ; 0.5 \%$ NASW), Mixed Heritage/biracial $(1.2 \%, n=24 ; 1.2 \%$ NASW), and other $(1.6 \%, n=34 ; 0.1 \%$ NASW $)$.

There was a greater degree of variation between this sample and the NASW findings in the area of primary work setting. A majority of the respondents were in private practice $(52.3 \%, n=1,083 ; 66.3 \%$ NASW) compared with $43.9 \%(n=908)$ in public practice $(33.7 \% \mathrm{NASW})$. As stated earlier, respondents were sampled based on selfreported primary practice area as determined by the NASW. The percentages given next for the U.S. sample, reflect those respondents who indicated multiple practice areas. Compared with the NASW findings, fewer of the respondents in this survey were in child/family welfare $(13.6 \%, n=281 ; 24.9 \% \mathrm{NASW})$, but more were working in mental health $(53.7 \%, n=1,112 ; 38.8 \%$ NASW $)$. The other areas of practice were similar to the NASW findings: criminal justice $(3.2 \%, n=66 ; 1.2 \%$ NASW $)$, medical health care $(15.4 \%, n=319 ; 13.0 \%$ NASW), occupational social work EAP $(2.5 \%, n=51 ; 0.8 \%$ NASW $)$, school social work $(6.7 \%, n=138 ; 5.2 \% \mathrm{NASW})$, and other $(17.6 \%, n=364$; $11.4 \%$ NASW).

The frequencies and percentages for the following additional demographic variables are reported in Table 1 (percentages have been rounded in the table and the discussion): region, race/ethnicity, areas of practice, primary work setting, location of practice, and employment level. There was little difference in race between the Norwegian and U.S. respondents. The majority of the 
respondents in Norway $(94 \%, n=563$ ) reported that they were Norwegian by ethnicity. In the United States, $89 \%$ ( $n$ $=1,847$ ) reported that they were Caucasian (specific European ancestry was not explored). In terms of primary work setting, Norwegian respondents had the option of voluntary work setting, which was not available in the United States. The voluntary designation was provided for Norwegian social workers who work for agencies such as Amnesty International. A public agency is funded by a government body. The private category indicated either private practice or a private agency, which may or may not be funded by public sources in Norway. Regarding areas of practice, $44 \%(n=265)$ of Norwegian respondents were engaged in child and social welfare services. A majority of U.S. respondents $(54 \%, n=1,112)$ were in the mental health area. The areas of practice are not included in Table 1 due to very different cultural categories.

\section{Religious and Spiritual Affiliations}

Social workers in Norway and the United States were asked to identify their current religious or nonreligious spiritual orientation(s) (see Table 2; percentages have been rounded

TABLE 1. Sample Characteristics by Country

\begin{tabular}{|c|c|c|}
\hline $\begin{array}{l}\text { DEMOGRAPHIC } \\
\text { INDICATOR }\end{array}$ & $\begin{array}{c}\text { RWAY }(N=601) \\
N(\%)\end{array}$ & $\begin{array}{c}\text { United STATES }(N=2,069) \\
N(\%)\end{array}$ \\
\hline \multicolumn{3}{|l|}{ Gender } \\
\hline Male & $112(19)$ & $512(25)$ \\
\hline Female & $488(81)$ & $1,539(74)$ \\
\hline Not reported & $1(<1)$ & $18(1)$ \\
\hline \multicolumn{3}{|l|}{ Ethnicity } \\
\hline African & $-(-)$ & $73(4)$ \\
\hline Hispanic & $-(-)$ & $34(2)$ \\
\hline Asian/Pacific Islander & $-(-)$ & $23(1)$ \\
\hline Native American/Alaskan & $n-(-)$ & $15(<1)$ \\
\hline Caucasian (Norwegian) & $563(94)$ & $1,847(89)$ \\
\hline Biracial/multiracial & $-(-)$ & $24(1)$ \\
\hline Saami & $4(<1)$ & $-(-)$ \\
\hline Other & $30(5)$ & $34(2)$ \\
\hline Not reported & $4(<1)$ & $19(1)$ \\
\hline \multicolumn{3}{|l|}{ Primary Work Setting } \\
\hline Private & $6(1)$ & $1,083(52)$ \\
\hline Statutory/public & $45(8)$ & $-(-)$ \\
\hline Not reported & $540(90)$ & $908(44)$ \\
\hline Tol tepol ted & $10(2)$ & $78(4)$ \\
\hline \multicolumn{3}{|l|}{ Location of Practice } \\
\hline Rural & & 357 (17) \\
\hline Suburban & $\begin{array}{l}158(26) \\
208(35)\end{array}$ & $\begin{array}{l}357(17) \\
740(36)\end{array}$ \\
\hline Urban & $\begin{array}{l}208(35) \\
227(38)\end{array}$ & $832(40)$ \\
\hline Not reported & $8(1)$ & $140(7)$ \\
\hline \multicolumn{3}{|l|}{ Employment Level } \\
\hline Full-time & 496 (83) & $1,541(75)$ \\
\hline Part-time & $80(13)$ & $440(21)$ \\
\hline Not reported & $25(4)$ & $88(4)$ \\
\hline
\end{tabular}

Note. Percentages have been rounded. in the table and in the discussion). The majority of Norwegian $(65 \%, n=390)$ and United States $(58 \%, n=$ $1,189)$ respondents were exclusively Christian. This percentage of Christians in the U.S. sample does not include those who reported an affiliation with Christianity and one or more additional affiliations/orientations (e.g., ChristianBuddhist, Christian-existentialist). Many of the respondents who reported multiple religious affiliations considered themselves to be Christian. Overall, a majority of the Norwegian respondents $(68 \%, n=403)$ and the U.S. respondents $(70 \%, n=1,456)$ reported a single religious affiliation.

Four categories were included under Singular Nonreligious Spiritual Affiliations and Orientations. None of the Norwegian social workers identified with Jewish nonaffiliated and agnosticism, compared with $2 \%$ $(n=42)$ and $3 \%(n=70)$, respectively, of the U.S. respondents. Atheists represented 2\% $(n=13)$ of the Norwegian respondents, and $2 \%(n=32)$ of the U.S. respondents. Finally, $14 \%(n=86)$ of the Norwegian respondents and $1 \%(n=13)$ of the U.S. respondents reported an affiliation with existentialism/humanism. A larger percentage of the Norwegian sample $(16 \%, n=99)$ reported a single nonreligious affiliation, compared with $8 \%(n=157)$ of the U.S. sample.

None of the respondents in Norway reported multiple religious or nonreligious affiliations. This was a significant contrast with the U.S. sample, in which 10\% $(n=204)$ of the social workers indicated that they had one religious affiliation and any other orientation (e.g., Christianity and Buddhism). Nearly 9\% $(n=188)$ of the U.S. sample selected multiple nonreligious affiliations (any combination of atheist, agnostic, existentialist, and nonaffiliated Jewish). Finally, 13\% $(n=80)$ of the Norwegian social workers and $3 \%(n=52)$ of the U.S. social workers reported that they did not have any religious or nonreligious affiliations. Missing data accounted for 3\% $(n=20)$ of the Norwegian and less than $1 \%(n=11)$ of the U.S. social workers.

Overall, a larger percentage of Norwegian social workers $(65 \%, n=390)$ reported a singular Christian affiliation. If the U.S. Christians (8\%) who indicated an additional religious orientation are included, the percentage of U.S. Christians is actually $66 \%$. The two countries exhibited a wider discrepancy in the area of nonreligious perspectives. Nearly $30 \%(n=179)$ of Norwegian social workers reported nonreligious affiliations, compared with over $19 \%(n=397)$ in the United States.

\section{Religious and Spiritual Practices of Respondents}

The respondents in both surveys were asked to address their personal experiences regarding religion and spirituality, which included their childhood and adult attendance in organized religious activities, their current relationship with and involvement in organized religious or support groups, and their participation in personal private reli- 
TABLE 2. Current Religious Affiliations/Spiritual Orientations of Social Workers by Country

\begin{tabular}{|c|c|c|c|c|}
\hline \multirow[b]{2}{*}{ AfFILIATION/ORIENTATION } & \multicolumn{2}{|c|}{$\operatorname{NORWAY}(N=601)$} & \multicolumn{2}{|c|}{ United StATES $(N=2,069)$} \\
\hline & $N$ & $\%$ & $N$ & $\%$ \\
\hline \multicolumn{5}{|l|}{ Singular Religious Affiliations and Orientations } \\
\hline Christian Catholic & 5 & 1 & 386 & 19 \\
\hline Christian Protestant (state chapter) & 360 & 60 & 623 & 30 \\
\hline Christian nondenominational & 25 & 4 & 75 & 4 \\
\hline Christian unspecified & - & - & 65 & 3 \\
\hline Latter Day Saints & - & - & 22 & 1 \\
\hline Eastern Orthodox & - & - & 10 & $<1$ \\
\hline Quaker & - & - & 8 & $<1$ \\
\hline Subtotal (Christian) & 390 & 65 & 1,189 & 58 \\
\hline Jewish Reform & - & - & 71 & 3 \\
\hline Jewish Orthodox & - & - & 2 & $<1$ \\
\hline Jewish Liberal & - & - & - & - \\
\hline Jewish Conservative & - & - & 36 & 2 \\
\hline Jewish unspecified & 1 & $<1$ & 14 & $<1$ \\
\hline Jewish other & - & - & 5 & $<1$ \\
\hline Subtotal (Jewish) & 1 & $<1$ & 128 & 6 \\
\hline Buddhism & 3 & $<1$ & 24 & 1 \\
\hline Hinduism & - & - & 2 & $<1$ \\
\hline Muslim & 2 & $<1$ & 1 & $<1$ \\
\hline Unitarian & - & - & 33 & 2 \\
\hline Traditional Native American & - & - & 6 & $<1$ \\
\hline Goddess religion & - & - & 6 & $<1$ \\
\hline Spiritism/shamanism & - & - & 4 & $<1$ \\
\hline Wicca & - & - & 3 & $<1$ \\
\hline Other & 6 & 1 & 61 & 3 \\
\hline \multicolumn{5}{|l|}{ Singular Nonreligious Affiliations and Orientations } \\
\hline Jewish nonaffiliated & - & - & 42 & 2 \\
\hline Agnosticism & - & - & 70 & 3 \\
\hline Atheism & 13 & 2 & 32 & 2 \\
\hline Existentialism/humanism & 86 & 14 & 13 & 1 \\
\hline \multicolumn{5}{|l|}{ Multiple Religious Affiliation/Orientation } \\
\hline $\begin{array}{l}\text { Any religious orientation in combination with any } \\
\text { other orientation (e.g., Christian and existentialist) }\end{array}$ & - & - & 204 & 10 \\
\hline $\begin{array}{l}\text { Multiple Nonreligious Affiliation/Orientation } \\
\text { Any combination of atheist, agnostic, existentialist, } \\
\text { nonaffiliated Jewish, and none }\end{array}$ & - & - & 188 & 9 \\
\hline \multicolumn{5}{|l|}{ No Affiliation/Orientation or Not Reported } \\
\hline No affiliation/orientation & 80 & 13 & 52 & 3 \\
\hline Not reported & 20 & 3 & 11 & $<1$ \\
\hline
\end{tabular}

Note. Percentages have been rounded.

gious or spiritual activities. The respondents were also asked to respond about negative perceptions of childhood and adulthood religious and spiritual experiences.

Childhood and adulthood religious community activities. Only 9\% $(n=52)$ of the Norwegian respondents reported active attendance on a daily to weekly basis in religious community services during childhood, compared with $67 \%(n=1395)$ of U.S. respondents. In Norway, however, the state religion is included in public school education. Participation on a daily to weekly basis declined even further during adulthood in both Norway $(4 \%, n=24)$ and the United States (33\%, $n=691$ ). Adult participation in Norway, however, increased in frequency in the cate- gories of "one to three times per month" $(13 \%, n=75)$ and "two to six times per year" $(23 \%, n=136)$, compared with participation during school years.

Private personal religious/spiritual participation. The respondents were asked the frequency of their private personal religious and spiritual practices such as meditation, visualization, and prayer; $27 \%(n=163)$ of the Norwegian respondents and $67 \%(n=1,392)$ of the U.S. respondents engaged in these activities on at least a weekly basis.

Present relationship to an organized religion or support group. The respondents were also asked to identify their present levels of participation and involvement in an organized religious or spiritual support group. In the 
United States, 52\% ( $n=1,077)$ of the sample indicated at least regular participation with some involvement, compared with $17 \%(n=104)$ in Norway. Half $(n=302)$ of the Norwegian respondents reported identification with a religious or spiritual group with very limited or no involvement, compared with $32 \%(n=667)$ of the U.S. sample.

Negative perceptions of religious and spiritual experiences. Using a 5-point Likert-type scale, respondents were asked to indicate their level of agreement from $1=$ "strongly disagree" to $5=$ "strongly agree," regarding negative childhood and adulthood religious and spiritual experiences. Negative childhood religious experiences were reported by $19 \%(n=112)$ of the Norwegian respondents and 20\% $(n=408)$ of the U.S. respondents. Negative childhood spiritual experiences were reported by $7 \%(n=42)$ of the Norwegian respondents and $8 \%$ ( $n=169)$ of the U.S. respondents. Current negative religious experiences were reported by $17 \%(n=104)$ of the
Norwegian respondents and $13 \%(n=268)$ of the U.S. respondents. Finally, current negative spiritual experiences were reported by $5 \%(n=28)$ of the Norwegian respondents and $1 \%(n=29)$ of the U.S. respondents. The Norwegian social workers were significantly more negative than U.S. social workers, about their current religious $(p=.01)$ and spiritual experiences $(p=.000)$. The four negative perception items were also reverse coded and summed to construct a scale with a range of 4 (very negative experiences) to 20 (very positive experiences), which measures perceived past and present negative religious and spiritual experiences for both Norway (Cronbach's alpha $=.80$ ) and the United States (Cronbach's alpha $=.69$ ). Overall, the Norwegian social workers felt significantly more negative $(p=.000)$ about their childhood and adulthood religious and spiritual experiences than did the U.S. social workers.

TABLE 3. Appropriate to Raise Topic of Religion/Spirituality by Client Issue by Country

\begin{tabular}{|c|c|c|c|c|c|c|c|c|c|}
\hline & \multirow[b]{2}{*}{ COUNTRY } & \multicolumn{4}{|c|}{ RELIGION } & \multicolumn{4}{|c|}{ SPIRITUALITY } \\
\hline & & $N$ & MEAN & $S D$ & SIG. & $N$ & MeAn & $S D$ & SIG. \\
\hline \multirow[t]{2}{*}{ Who has a terminal illness } & NOR & 596 & 3.03 & 1.25 & $\star \star \star$ & 597 & 3.58 & 1.11 & $\star * *$ \\
\hline & U.S. & 2,055 & 3.88 & 1.11 & & 2,061 & 4.33 & 0.87 & \\
\hline \multirow[t]{2}{*}{ Who has a substance abuse disorder } & NOR & 597 & 2.41 & 1.03 & $\star * *$ & 596 & 3.13 & 1.09 & $* * *$ \\
\hline & U.S. & 2,058 & 3.19 & 1.20 & & 2,058 & 3.90 & 1.03 & \\
\hline \multirow[t]{2}{*}{ Who is preparing to become a foster parent } & NOR & 593 & 3.22 & 1.27 & $* \star *$ & 595 & 3.72 & 1.04 & ns \\
\hline & U.S. & 2,063 & 3.58 & 1.15 & & 2,063 & 3.75 & 1.04 & \\
\hline \multirow[t]{2}{*}{ Who is recovering from sexual abuse } & NOR & 592 & 2.23 & .99 & $* * *$ & 591 & 2.86 & 1.11 & $* \star *$ \\
\hline & U.S. & 2,056 & 3.23 & 1.20 & & 2,054 & 3.79 & 1.04 & \\
\hline \multirow{2}{*}{$\begin{array}{l}\text { Who is experiencing, or has experienced, } \\
\text { partner violence }\end{array}$} & NOR & 588 & 2.23 & .98 & $\star \star \star *$ & 594 & 2.81 & 1.09 & $\star \star \star *$ \\
\hline & U.S. & 2,044 & 3.20 & 1.17 & & 2,044 & 3.69 & 1.05 & \\
\hline \multirow{2}{*}{$\begin{array}{l}\text { Who is suffering the effects of a natural } \\
\text { disaster (e.g., flood) or catastrophe (e.g., } \\
\text { airline/train crash) }\end{array}$} & NOR & 593 & 2.50 & 1.09 & $\star \star *$ & 593 & 3.07 & 1.10 & $\star \star \star$ \\
\hline & U.S. & 2,045 & 3.44 & 1.17 & & 2,047 & 3.87 & 1.02 & \\
\hline \multirow[t]{2}{*}{ Who is bereaved } & NOR & 592 & 3.02 & 1.15 & $\star * *$ & 595 & 3.47 & 1.09 & $\star \star \star *$ \\
\hline & U.S. & 2,051 & 3.89 & 1.08 & & 2,049 & 4.22 & 0.89 & \\
\hline \multirow{2}{*}{$\begin{array}{l}\text { Who is suffering from a chronic } \\
\text { mental disorder }\end{array}$} & NOR & 593 & 2.30 & 1.00 & $\star \star *$ & 596 & 2.86 & 1.09 & $\star * \star$ \\
\hline & U.S. & 2,048 & 3.05 & 1.17 & & 2,052 & 3.47 & 1.10 & \\
\hline \multirow[t]{2}{*}{ Who is suffering from a loss of job } & NOR & 595 & 2.10 & .91 & $\star \star \star$ & 596 & 2.64 & 1.04 & $\star \star \star$ \\
\hline & U.S. & 2,049 & 3.08 & 1.15 & & 2,052 & 3.55 & 1.08 & \\
\hline \multirow{2}{*}{$\begin{array}{l}\text { Who is experiencing difficulty in } \\
\text { family relations }\end{array}$} & NOR & 595 & 2.25 & .97 & $* * *$ & 596 & 2.84 & 1.08 & $\star \star \star *$ \\
\hline & U.S. & 2,049 & 3.27 & 1.14 & & 2,054 & 3.68 & 1.03 & \\
\hline \multirow{2}{*}{$\begin{array}{l}\text { Who is involved in the criminal } \\
\text { justice system }\end{array}$} & NOR & 595 & 2.16 & .94 & $\star \star *$ & 596 & 2.79 & 1.10 & $\star * *$ \\
\hline & U.S. & 2,052 & 3.14 & 1.14 & & 2,055 & 3.59 & 1.05 & \\
\hline \multirow[t]{2}{*}{ Practice Issues Scale } & NOR & 569 & 27.46 & 9.69 & $\star * *$ & 578 & 33.74 & 10.11 & $* * *$ \\
\hline & U.S. & 1,998 & 36.93 & 11.07 & & 2,009 & 41.87 & 9.62 & \\
\hline
\end{tabular}

Note. Means and standard deviations are based on valid responses. Missing cases are excluded.

Significance levels: $n s$ (not significant); *** (.000 level) 
Religion and Spirituality Practice Issues (RSPI) Scale

A major issue explored by this survey was social workers' attitudes toward religion and spirituality and how these concepts affect the helping relationship. Twenty-two questions in the survey dealt with raising the topic of religion or spirituality with clients dealing with specific practice issues (see Table 3).

Most respondents in both Norway and the United States believed it was more appropriate to raise the topic of spirituality in a nonsectarian manner than religion with clients on each issue. Fifty percent or more of the Norwegian social workers believed that it is appropriate to raise the topic of spirituality in a nonsectarian manner with clients regarding terminal illness $(66 \%, n=396)$, foster parents $(70 \%, n=418)$, and with the bereaved $(61 \%, n=369)$, compared with U.S. social workers who believed it is appropriate for all of the client issues presented in the questionnaire. Introducing religion with specific client issues was limited to foster parents $(52 \%, n=311)$ in the Norwegian sample. In the United States, $50 \%$ or more of the sample approved in the areas of terminal illness $(73 \%$, $n=1,507)$, foster parents $(62 \%, n=1,279)$, the bereaved $(75 \%, n=1,543)$, and natural disaster $(55 \%, n=1,127)$. Respondents from both countries approve of nonsectarian spirituality over religion when applying them to practice issues.

Three scales were used to examine the relationships among religion, spirituality, and client issues. The Religion Practice Issues Scale (RPIS) was constructed for Norway (Cronbach's alpha $=.95$ ) and the United States (Cronbach's alpha $=.97$ ) by summing the 11 items on religion. The Spirituality Practice Issues Scale (SPIS) was constructed for Norway (Cronbach's alpha $=.97$ ) and the United States (Cronbach's alpha $=.96$ ) by summing the 11 items on

TABLE 4A. Spiritually Oriented Helping Activities by Country

\begin{tabular}{|c|c|c|c|c|c|c|c|}
\hline \multirow[t]{2}{*}{ HELPING ACTIVITY } & \multirow[t]{2}{*}{ COUNTRY } & \multicolumn{3}{|c|}{$\begin{array}{l}\text { Have Personally } \\
\text { Done With Clients }\end{array}$} & \multicolumn{3}{|c|}{$\begin{array}{c}\text { IS AN APPROPRIATE } \\
\text { HELPING ACTIVITY (INTERVENTION) }\end{array}$} \\
\hline & & $N$ & $\%$ & SIG. & $N$ & $\%$ & SIG. \\
\hline \multirow[t]{2}{*}{ Use or recommend religious or spiritual books or writings } & NOR & 112 & 19 & $\star * \star$ & 258 & 44 & $\star * *$ \\
\hline & U.S. & 1,197 & 59 & & 1,577 & 81 & \\
\hline \multirow[t]{2}{*}{ Pray privately for a client } & NOR & 110 & 18 & $\star * *$ & 192 & 33 & *** \\
\hline & U.S. & 1,167 & 58 & & 1,344 & 71 & \\
\hline \multirow[t]{2}{*}{ Pray with a client } & NOR & 22 & 4 & $\star \star \star$ & 114 & 20 & $\star \star *$ \\
\hline & U.S. & 571 & 28 & & 980 & 52 & \\
\hline \multirow[t]{2}{*}{ Use religious language or concepts } & NOR & 127 & 22 & $* * *$ & 227 & 39 & *** \\
\hline & U.S. & 1,371 & 68 & & 1,482 & 76 & \\
\hline \multirow[t]{2}{*}{ Use nonsectarian spiritual language or concepts } & NOR & 451 & 77 & $\star \star \star$ & 508 & 87 & $* * *$ \\
\hline & U.S. & 1,750 & 87 & & 1,817 & 93 & \\
\hline \multirow{2}{*}{$\begin{array}{l}\text { Recommend participation in a religious or spiritual } \\
\text { support system or activity }\end{array}$} & NOR & 158 & 27 & $\star \star \star$ & 289 & 50 & $\star \star \star$ \\
\hline & U.S. & 1,639 & 81 & & 1,728 & 88 & \\
\hline \multirow[t]{2}{*}{ Touch clients for "healing" purposes } & NOR & 3 & $<1$ & $\star \star \star *$ & 28 & 5 & $\star \star \star *$ \\
\hline & U.S. & 296 & 15 & & 472 & 24 & \\
\hline \multirow{2}{*}{$\begin{array}{l}\text { Help clients develop religious or spiritual rituals as a } \\
\text { clinical intervention }\end{array}$} & NOR & 73 & 12 & $\star * \star$ & 185 & 32 & $\star \star \star$ \\
\hline & U.S. & 1,281 & 63 & & 1,591 & 81 & \\
\hline \multirow{2}{*}{$\begin{array}{l}\text { Participate in client's religious or spiritual rituals as a } \\
\text { practice intervention }\end{array}$} & NOR & 41 & 7 & $\star \star \star$ & 118 & 20 & $\star * *$ \\
\hline & U.S. & 369 & 18 & & 720 & 38 & \\
\hline \multirow{2}{*}{$\begin{array}{l}\text { Encourage the client to do regular religious or spiritual } \\
\text { self-reflective diary keeping or journal keeping }\end{array}$} & NOR & 348 & 58 & ns & 538 & 91 & $\star \star *$ \\
\hline & U.S. & 1,093 & 54 & & 1,610 & 82 & \\
\hline \multirow{2}{*}{$\begin{array}{l}\text { Discuss the role of religious or spiritual beliefs in } \\
\text { relation to significant other }\end{array}$} & NOR & 262 & 44 & $\star \star \star$ & 416 & 71 & $\star * *$ \\
\hline & U.S. & 1,637 & 81 & & 1,784 & 90 & \\
\hline \multirow{2}{*}{$\begin{array}{l}\text { Assist clients to reflect critically on religious or spiritual } \\
\text { beliefs and practices }\end{array}$} & NOR & 186 & 31 & $\star \star \star$ & 342 & 58 & $* * *$ \\
\hline & U.S. & 1,292 & 64 & & 1,508 & 77 & \\
\hline
\end{tabular}

Note. Significance Levels: $n s$ (not significant); *** (.000 level). Valid percentages have been rounded; missing values are excluded. 
TABLE 4в. Spiritually Oriented Helping Activities by Country

\begin{tabular}{|c|c|c|c|c|c|c|c|}
\hline \multirow[t]{2}{*}{ Helping Activity } & \multirow[t]{2}{*}{ COUNTRY } & \multicolumn{3}{|c|}{$\begin{array}{l}\text { Have Personally } \\
\text { Done with Clients }\end{array}$} & \multicolumn{3}{|c|}{$\begin{array}{c}\text { IS AN APPROPRIATE } \\
\text { HELPING ACTIVITY (INTERVENTION) }\end{array}$} \\
\hline & & $N$ & $(\%)$ & SIG. & $N$ & $(\%)$ & SIG. \\
\hline \multirow{2}{*}{$\begin{array}{l}\text { Help clients assess the meaning of spiritual experiences } \\
\text { that occur in dreams }\end{array}$} & NOR & 88 & 15 & \multirow[t]{2}{*}{$\star \star \star$} & 214 & 37 & \multirow[t]{2}{*}{$\star \star *$} \\
\hline & U.S. & 751 & 37 & & 1,309 & 67 & \\
\hline \multirow{2}{*}{$\begin{array}{l}\text { Help clients consider the spiritual meaning and purpose } \\
\text { of his or her current life situation }\end{array}$} & NOR & 242 & 41 & \multirow[t]{2}{*}{ *** } & 408 & 69 & \multirow[t]{2}{*}{$* * *$} \\
\hline & U.S. & 1,432 & 71 & & 1,635 & 83 & \\
\hline \multirow{2}{*}{$\begin{array}{l}\text { Help clients reflect on their belief about what happens } \\
\text { after death }\end{array}$} & NOR & 118 & 20 & \multirow[t]{2}{*}{$* * *$} & 339 & 58 & \multirow[t]{2}{*}{$* * *$} \\
\hline & U.S. & 1,454 & 72 & & 1,728 & 87 & \\
\hline \multirow{2}{*}{$\begin{array}{l}\text { Help clients consider the ways their religious or spiritual } \\
\text { support systems are helpful }\end{array}$} & NOR & 206 & 35 & \multirow[t]{2}{*}{$* * *$} & 411 & 70 & \multirow[t]{2}{*}{$\star \star * *$} \\
\hline & U.S. & 1,910 & 94 & & 1,941 & 97 & \\
\hline \multirow{2}{*}{$\begin{array}{l}\text { Help clients consider the ways their religious or spiritual } \\
\text { support systems are harmful }\end{array}$} & NOR & 178 & 30 & \multirow[t]{2}{*}{$* * *$} & 390 & 66 & \multirow[t]{2}{*}{$* * *$} \\
\hline & U.S. & 1,427 & 71 & & 1,702 & 87 & \\
\hline
\end{tabular}

Note. Significance Levels: ns (not significant); *** (.000 level)

Valid percentages have been rounded; missing values are excluded.

spirituality. Finally, a third scale, the combined Religion and Spirituality Practice Issues Scale (RSPIS), summed the 22 religion and spirituality items for Norway (Cronbach's alpha $=.97$ ) and the U.S. social workers (Cronbach's alpha $=.97$ ). All scale items were positively worded and allowed respondents to answer using a 5-point Likert-type scale ranging from $1=$ "strongly disagree" to $5=$ "strongly agree." The range on the RPIS and the SPIS is 11 to 55 . The range on the RSPIS is 22 to 110 .

When comparing Norway and the U.S. mean ratings on the individual religion and spirituality items and on the practice issues scales (see Table 3), it becomes clear that the U.S. social workers responded in a significantly more positive manner $(p=.000)$, except on the foster parent item in relation to spirituality.

\section{Helping Activities}

Respondents were presented a list of 17 helping activities and asked to indicate which they had personally used with clients (see Table 4a).

The responses from those providing sufficient information for the intervention items were dichotomized $(0=$ no, 1 = yes) and summed into a single score. The Cronbach's alpha is .84 for the Norway measure and .81 for the U.S. measure. The range of the measure is 0 (no interventions) to 17 (all interventions have been used). Only 10\% $(n=61)$ of Norwegian practitioners who responded to these questions had not used any interventions, compared with $1 \%(n=24)$ of the U.S. sample. With the exception of diary and journal keeping, social workers in the United States $(n=2,045$, mean $=10.09, s d=3.69$ ) were significantly more likely $(p=$ $.000)$ than Norwegian social workers $(n=596$, mean $=4.57$, $s d=3.54$ ) to actually use the helping activities.

Over $50 \%$ of the social workers in Norway had used nonsectarian spiritual language or concepts and encouraged clients to keep a diary or journal. With the exception of praying with a client, touching a client for healing purposes, participating in a client's religious/spiritual rituals, and helping a client assess the meaning of spiritual experiences that occur in dreams, over $50 \%$ of U.S. respondents had used at least one of the helping activities listed in the survey instrument.

Respondents were also asked to identify the appropriateness of each helping activity item in social work practice. The responses to these questions were dichotomized $(0=$ no, $1=$ yes) and summed into a single score. The Cronbach's alpha for Norway is .86, and for the United States it is .85 . The range of the measure is 0 (no interventions are appropriate) to 17 (all interventions are appropriate). Only $2 \%(n=14)$ of Norwegian respondents and nearly $1 \%(n=16)$ of U.S. respondents who answered these questions felt that all interventions are inappropriate. On the other hand, almost $8 \%(n=159)$ of U.S. respondents felt that all interventions are appropriate compared with $1 \%(n=7)$ of the Norwegian respondents.

A higher percentage of respondents in both countries indicated that it is appropriate to use a spiritually oriented activity than those who actually did use it. Respondents in the United States $(n=2,045$, mean $=12.34, s d=3.67)$ were significantly more likely $(p=.000)$ to approve of the appropriateness of the helping activities than their counterparts in Norway $(n=596$, mean $=8.35, s d=4.10)$. One activity, however, diary keeping, was deemed to be more appropriate by Norwegian respondents $(p=.000)$ than U.S. respondents.

\section{Other Practice Issues}

A majority of Norwegian social workers $(79 \%, n=472)$ and U.S. social workers $(87 \%, n=1,806)$ agreed or strongly agreed that spirituality is a fundamental part of 
being human. When asked, however, whether social work practice with a spiritual component has a better chance to empower clients than one without, only $41 \%(n=242)$ of Norwegian respondents agreed or strongly agreed compared with $60 \%(n=1,242)$ of the U.S. respondents.

Spiritual assessment/history. When asked whether taking a client's religious history or a spiritual history should be part of intake and assessment, 58\% $(n=1,202)$ of U.S. respondents agreed or strongly agreed that a religious history should be taken, and 59\% $(n=1,220)$ agreed or strongly agreed that a spiritual history should be taken. As stated earlier, spiritual assessment is not commonly used in Norway, but some social workers agreed that a religious history $(16 \%, n=94)$ and a spiritual history $(21 \%$, $n=129$ ) should be taken.

Forgiveness issues. Among U.S. respondents, 59\% ( $n=$ 1,225 ) indicated that it is important to help clients with forgiveness issues, compared with $28 \%(n=172)$ in Norway. A greater percentage of both Norwegian (31\%, $n=187)$ and U.S. $(72 \%, n=1,492)$ respondents, however, actually applied forgiveness techniques practice.

Referrals to clergy. Many U.S. social workers $(71 \%, n=$ $1,467)$ had used referrals to religious or spiritual leaders. In Norway, however, fewer respondents (44\%, $n=267)$ did so. This was much higher than expected, given the levels of scepticism about religion and spirituality in practice.

\section{Values and Ethical Issues}

The survey instruments included items on ethical concerns related to the topic of religion and spirituality. In Norway, $42 \%(n=257)$ believed that integrating religion and spirituality in social work practice does not conflict with social work's mission, compared with $74 \%(n=1,529)$ of U.S. respondents. In terms of the FO Code of Ethics, only 39\% $(n=235)$ of Norwegian social workers believed that a social work practice that integrates religion and spirituality does not conflict with the ethical code, compared with $68 \%(n=1,397)$ of U.S. respondents in reference to the NASW ethical code.

\section{Discussion}

A majority of the social workers in both countries were Christian. A majority of social workers in Norway $(72 \%, n$ $=433)$ and the United States $(90 \%, n=1,862)$ indicated that social workers should become more knowledgeable about spiritual matters. Nearly $80 \%(n=472)$ of Norwegian and $87 \%(n=1,806)$ of U.S. respondents indicated that spirituality is a fundamental aspect of being human, yet $54 \%(n=324)$ of Norwegian and $73 \%(n=$ $1,516)$ in the United States had not received instruction on this issue. Since many social workers were trained before religion and spirituality became a concern, continuing education can play a large role in both countries, and current initiatives by the Rammeplan and CSWE can be used to shape curricula in schools of social work.

The social work profession in the United States has a longer history compared with Norway. The U.S. profession, for example, traces its roots to the United Kingdom and the 1601 Elizabethan poor laws, and it was strongly sectarian until the 1920s. In Norway, social work was professionalized at a time when the United States and Western Europe were undergoing secularization. Norway was occupied by the Nazis for a period of 5 years, which severely restricted the role of social work. In the 1950 s, social work emerged with a more secular perspective. During the same period, the United States was impacted by McCarthyism, which inhibited the influence of Marxism in all facets of life, including the social work profession (Reisch \& Andrews, 2001). Norway is more secular than the United States. A secularist environment strongly impacts an individual's consciousness and permeates all areas of social life (Borg \& Wright, 1998). Thus, the differences in the degree of secularization in each country could influence the differences found in the survey responses.

In the U.S. sample, a majority of the respondents were in private settings, whereas in Norway, the majority were in public settings. This distinction may have an impact on how religion and spirituality are approached in the work setting. Norway's public sector may not offer an occasion where practice activities that include religion and spirituality are appropriate.

Given the U.S. guidelines and the Norwegian Rammeplan for including religion and spirituality in the curriculum, there are a number of concerns for both countries to consider. Many of the respondents in Norway $(58 \%, n=335)$ graduated in the 1990s. Within the past few years, new and established schools of social work are not as committed to the Marxist-influenced ideology of the 1970 s, creating an environment in which the profession is more open to the subject of religion and spirituality. Also, Norway is becoming an increasingly heterogenous society. A third of the Norwegian respondents tended to be neutral regarding the answers to just about all of the questions, indicating that they are ambivalent about religion and spirituality. This could be interpreted as a sign of more openness among Norway's social workers. Educators need to learn more about the challenges that practitioners face regarding religion and spirituality in increasingly heterogenous societies, which has implications for spiritual assessment.

\section{Implications for Practice}

According to Sheridan (2002), spiritually sensitive social work practice comprises seven interrelated elements: theory, practice goals, practice context, the helping relationship, assessment, intervention, and ethics. This survey did not address theories such as Fowler's (1981) stages of faith 
development or Wilber's (1995) full spectrum model of consciousness, nor did it inquire about the social workers context for spiritual practice. Additionally, the survey did not have questions that dealt specifically with the nature of the helping relationship. Specifically, respondents were not asked if they critically examine their own biases and prejudices regarding religious and spiritual diversity.

\section{Practice Goals}

The survey explored issues of meaning and human potential in practice by asking the respondents whether or not they agreed that spirituality is a fundamental aspect of being human. Both countries overwhelmingly agreed. Their responses affirmed the strengths-perspective approach to practice (Saleeby, 1997). By including spirituality and religion when addressing a client's needs, the social worker broadens the client's resources and support base and is given an opportunity to collaborate with the client's spiritual and/or religious leaders. A majority of the U.S. social workers in this sample did collaborate with their clients' spiritual and religious leaders (Furman \& Fry, 2000 ). In contrast, less than half of Norwegian social workers did so, which may be an artifact of the nonseparation of church and state in Norway, especially if clients' church attendance and involvement is limited to baptism, marriage, and death. Given the influx of faith-based immigrants, however, collaborating with a spiritual leader such as an imam could prove beneficial.

\section{Assessment}

A client's religious and spiritual history can be an important part of comprehensive assessment, but practitioners need to move "beyond the surface features of faith affiliation (such as Protestant, Catholic, Jewish, or Muslim) to include deeper facets of a person's spiritual life" (Sheridan, 2002, p. 568). Canda and Furman (1999) and Hodge (2003) have developed guidelines and suggestions that would help social workers in this area. Nearly $60 \%$ of U.S. respondents agreed that taking a religious $(n=1,202)$ or spiritual history $(n=1,220)$ should be part of intake and assessment. In Norway, spiritual or religious assessment is commonly not used. Given the low response to this question, perhaps the Norwegian respondents had not been exposed to this aspect of assessment.

\section{Interventions}

Tables $4 \mathrm{a}$ and $4 \mathrm{~b}$ contain several helping activities that can be used for intervention (see Sheridan (2002) for additional suggestions). Although the U.S. respondents were, overall, quite comfortable with the use and appropriateness of the suggested activities, the Norwegian social workers seemed to be ambivalent. The same was true regarding the appropriateness of raising the topics of religion and spirituality with clients (see Table 3). The U.S. social workers were quite comfortable raising the topics of religion and spiritual with clients coping with grief, bereavement natural disasters, and mental distress. The Norwegian social workers, however, were reticent about raising the topic about any problematic situation. The concept of forgiveness was explored in separate questions. The U.S. social workers $(59 \%, n=1,225)$ felt that forgiveness was an important intervention, compared with $28 \%(n=172)$ of the Norwegian social workers. It must be remembered that many Norwegian social workers only have been dealing with this concept since 1999. Also, it is possible that the U.S. subjects responded due to a special interest in the subject matter.

\section{Ethics}

Canda and Furman (1999) have provided an ethical framework for using spiritually based activities and interventions appropriately and responsibly. Among U.S. respondents, $74 \%(n=1,529)$ felt that integrating religion and spirituality in social work practice was ethical and in line with social work's mission. Approximately $42 \%$ ( $n=$ 257) of Norwegian social workers felt the same way. As suggested in tables $4 \mathrm{a}$ and $4 \mathrm{~b}$, U.S. social workers were significantly more likely $(p=.000)$, with the exception of diary keeping or journal writing, to view the spiritually oriented helping activities as ethically appropriate, compared with their Norwegian peers. As in the United States, a larger percentage of Norwegian social workers viewed the helping activities as appropriate, compared with those who had actually used them. Overall, however, Norwegian social workers were not as likely to use or to approve of the helping activities, compared with U.S. social workers. Again, Norwegian social workers appeared to be more cautious, which may be due to the relatively recent introduction of the concepts of religion and spirituality to Norwegian social work.

The findings from this survey research substantiates four of Sheridan's (2002) suggested components for spiritually based practice. It also opens the door for dialoguing with social workers from all over the world about universal and ethically appropriate assessment techniques and intervention activities.

\section{International Collaboration on Religion, Spirituality, and Social Work}

As Midgley has observed, knowledge can be increased by investigating phenomena in other countries. There appears to be a universal directive to bring religion and spirituality into the curriculum, as noted in the working papers by the International Association of Schools of Social Work (IASSW) and the International Federation of Social Workers (IFSW) (2002). The results from the helping activities in both countries, for example, showed that acceptance was high regarding the appropriateness of such practices. As organizations such as the IASSW and the IFSW continue to work to define the principles of global social work education and practice, and as social workers undertake the 
task of obtaining knowledge and understanding of the role of religion and spirituality among diverse populations within the context of human rights, comparative studies that examine social workers' attitudes about religion and spirituality can be used to motivate and inform social workers who are integrating this subject in education and practice. Even though the United States is at a different point in the process, both the United States and Norway are still faced with the challenges that human rights issues pose for practitioners and educators alike. The U.S. and Norway findings can also be helpful to other countries who are just beginning to explore these issues in respect to their own educational systems and practices, and translate them for cultural appropriateness.

As Canda (2002) suggested, international collaboration on spirituality and social work should be guided by principles of mutual respect, learning from each others' experiences, and avoidance of U.S. tendencies to impose U.S. standards and assumptions on other countries.

There were some puzzling findings in the Norway survey that merit further research. The literature review regarding Norwegian society and social work suggested that there is a higher level of secularization in society generally as well as suspicion of dealing with religion in professional work, as compared with the United States. Most Norwegians agreed that spirituality is a fundamental aspect of being human. In addition, Norway has a state church, which would be impossible in the United States, given Constitutional separation of church and state. To complicate this further, Norwegian responses regarding the incorporation of religion and spirituality in social work practice show an overall pattern of lower utilization than in the United States. Perhaps more in-depth qualitative interview studies with Norwegian social workers would help to illuminate reasons for this complex mix of secularization, state church, and lower practice utilization of spirituality.

\section{Concluding Remarks}

In conclusion, findings of this international comparative study support recent trends of relevant international social welfare organizations that promote a holistic conception of the person, including spirituality, and respect for human diversity, including religious diversity. For example, the World Health Organization recognizes health as consisting of overall well-being in physical, mental, and social aspects, including respect for religion (e.g., Jabbour \& Fouad, 2004). The United Nations (1948) Declaration of Human Rights, Article 18, emphasizes the right to religious freedom. The IASSW/IFSW (2002) Global Standards for Social Work Education and Training (Article 4.2.4) acknowledges religion as an aspect of human diversity and also refers to the holistic biopsychosocial, spiritual model of human behavior (p. 15, note 13). Similarly, the IASSW/IFSW Ethical Document (Section 4.1) states that "social workers should uphold and defend each person's physical, psychological, emotional and spiritual integrity and well-being." (IASSW, 2004). Ideally, this study will encourage further collaboration and synergy between social workers in various countries to promote ways of responding to the spiritual interests of people, while respecting diversity of religious and nonreligious perspectives in keeping with professional social work values.

\section{References}

Aasland, A. (1937). Fagutdannelse. Socialt arbeid og utdannelse for det (Vocational training. Social work and training for it). In Einar Storsteen (Ed.), Social Håndbok for Norge (Handbook for Norway) (pp. 265-269). Oslo, Norway: Norsk Forening for Socialt Arbeid.

Berger, Peter. L. (1999). The desecularization of the world: A global overview. In P. Berger (Ed.), The desecularization of the world: Resurgent religion and world politics. Washington, DC: Ethics and Public Policy Center.

Borg, M. J., \& Wright, N. T. (1998). The meaning of Jesus: Two visions. San Francisco: HarperSanFrancisco.

Botvar, P. K. (1996). Belonging without believing? The Norwegian religious profile compared with the British one. In P. Repstad (Ed.), Religion and modernity: Modes of co-existence (pp. 119-134). Oslo, Norway: Scandinavian University Press.

Bruce, S. (1995). Religion in modern Britain. Oxford, England: Oxford University Press.

Bruce, S. (1996). Religion in the modern world: From cathedrals to cults. Oxford, England: Oxford University Press.

Canda, E. R. (1990a). Afterword: Spirituality re-examined. Spirituality and Social Work Communicator, 1(1), 13-14.

Canda, E. R. (1990b). A holistic approach to prayer for social work practice. Social Thought, 16(3), 3-13.

Canda, E. R. (2002). A world wide view on spirituality and social work: Reflections from the USA experience and suggestions for relevant material. Currents: New Scholarship in the Human Services. Retrieved April 11, 2005, from http://fsw.ucalgary.ca/currents

Canda, E. R., \& Furman, L. (1999). Spiritual diversity in social work practice: The heart of helping. New York: Free Press.

Council on Social Work Education (CSWE). (2001). Educational policy and accreditation standards. Washington, DC: Council of Social Work Education.

Council on Social Work Education (CSWE). (2003). Handbook of accreditation standards and procedures. Alexandria, VA: Council of Social Work Education.

Davie, G. (1999). Europe: The exception to the rule? In P. Berger (Ed.), The desecularization of the world: Resurgent religion and world politics (pp. 65-83). Washington, DC: Ethics and Public Policy Center.

Derezotes, D., \& Evans, K. (1995). Spirituality and religiosity in practice: Indepth interviews of social work practitioners. Social Thought, 18(1), $39-56$.

Dudley, J., \& Helfgott, C. (1990). Exploring a place for spirituality in the social work curriculum. Journal of Social Work Education, 260, 287-294.

Fowler, J. F. (1981). Stages of faith: The psychology of human development and the quest for meaning. San Francisco: Harper.

Furman, L., Benson, P., Grimwood, C., \& Canda, E. R. (2004). Religion and spirituality in social work education and direct practice at the millennium: A survey of UK social workers. British Journal of Social Work, 34(6), 767-792.

Furman, L., \& Chandy, J. M. (1994). Religion and spirituality: A long-neglected cultural component of rural social work practice. Human Services in the Rural Environment, 17(3/4), 21-26.

Furman, L., \& Fry, S. (2000). Clerics and social workers: Collaborators or competitors? Arete, 24(1), 30-39.

Gallup, G., \& Lindsay, D. M. (1999). Surveying the religious landscape: Trends in U.S. beliefs. Harrisburg, PA: Morehouse.

Gibelman, M., \& Schervish, P.H. (1997). Who we are: A second look. Washington, DC: NASW Press. 